\title{
ENGINEERING LABOUR MARKET IN CONSTRUCTION IN UKRAINE AND ABROAD
}

\author{
Ljudmila Shumak ${ }^{1}$
}

\begin{abstract}
The purpose of the article is to analyse the engineering labour market on the example of the profession of design engineer in modern conditions of the construction market in Ukraine and abroad. It is also necessary to study the formation of the integrated view of the structure, state and dynamics of the labour market in design enterprises; qualification requirements for engineers; compliance of the vocational education system with these requirements. Design is a type of labour activity in construction as a branch of professional activity. The article contains statistical indicators of wages that characterize the profession of design engineer, and innovative activities of design enterprises. The indicator of the level of innovative development of design enterprises is the quality of products (projects). One of the main characteristics of design is the price of the product. It includes the Customer's assessment of all other design properties. Pricing issues have been and continue to be one of the guiding problems of the country's construction industry, including design and the salaries of design engineers. Methodology. The design market in Ukraine has a situation that reflects the overall state of the construction industry. The development of this type of business and its participants is differently influenced by many factors. Project market participants in Ukraine can be classified: by the form of ownership - state departmental institutions and commercial structures; by the volume of work - design enterprises and design institutes that act as general designers, who mainly perform all stages of the project. Architectural workshops, mainly specializing in the stages of "sketch project" and "project"; design departments at the construction and assembly organizations performing stages "working design", "working documentation", separate sections of projects or only detailing for production. There were about 70 design enterprises and about 200 architectural workshops in Kyiv in 2016, according to the Association of Design Enterprises. The potential of Ukraine as a "technical" state, that is able to solve complex problems and generate complex solutions and products with high added value, is due to the potential of the educational field of technical direction. Accordingly, in 2016 in Ukraine, the relative number of graduates of technical specialties was 2 times more than in the UK or Poland, namely, in European countries, thousands of people: Ukraine - 130; France - 105; Germany - 93; Turkey - 75; Great Britain - 71; Poland - 66; Spain - 56; Italy - 48; Romania - 39. In 2015-2016, training in the fields of construction specialties in Ukraine was carried out by 49 higher education institutions. Today, one of the shortcomings of education is the lack of modern curricula; technical fields are getting excessively humanitarian and detachment from practice, in particular, the application of European standards. Some Western academic subjects are not taught in Ukrainian universities at all, which reduces the competitiveness of graduates. Certification of responsible executors of design works in construction in 2012 was a significant step towards the liberalization of the market of design services. The responsibility of engineers was personified and strengthened, but at the same time their object and financial possibilities were increased. As of December 2015, more than 22,000 design engineers have been certified in Ukraine. It can be stated that for the period 2016-2019, a fairly developed market of design services has been formed in Ukraine. Its key features are the attraction to large cities, diversification by specialties and grounds on the existing, including the Soviet, experience, as well as concentration and duplication of functions, in particular, design institutes by the commercial sector, etc. Significant potential is due to intellectual capacity, diversity of tasks and the accumulated practice of Ukrainian designers, which provides certain advantages in the international market of design services. Today, the customer is moving away from design technologies, which means that the designer's work must be built in such a way that the customer understands the need for investment at the design stage of the facility, taking into account further operation. The lack of design and the need to revise salaries affects the value of real estate. The lack of engineers affects the organization of construction and the market as a whole. Increasing the salaries of design engineers, creating more favourable working conditions lead
\end{abstract}

Corresponding author:

${ }^{1}$ Kyiv National University of Construction and Architecture, Ukraine.

E-mail: shumak-ljudmila@ukr.net

ORCID: https://orcid.org/0000-0002-5738-5744 
to an increase in the cost of construction work from 9 to $15 \%$. Understanding the difficulties faced by the design industry, it is logical to think about the ways to overcome them in the near future. Conclusion. Nowadays, during the COVID-19 pandemic, the analysis of the engineering labour market in construction allows to understand the innovative activity of the project enterprise and to mark the course of further development of the market of design services in Ukraine. Reducing unhealthy competition among designers is possible due to new approaches to work aimed at optimizing and improving the performance of design companies. Stories of design engineers having to leave their favourite profession to make a living are a thing of the past. Now it is a prestigious and profitable speciality. To be relevant in the profession, you must, first of all, learn foreign languages, read technical literature in English. Self-education, i.e. the ability to independently search and analyse information, to develop oneself as a specialist, is of great importance. High erudition is a quality possessed by the Soviet-era engineers and often lacking in many modern design engineers. At the same time, it is of great importance because the building is a single organism, and the design engineer must understand not only construction, but also related fields. The main feature that distinguishes a design engineer is a certain mindset. And the work must be highly paid for this. Considering the issue of the engineering labour market in Ukraine, it is safe to say that there are temporary professions that are in vogue, and there are those that will always be in demand, and the profession of design engineer is one of them.

Key words: engineering labour market, design engineer, salary, project services, innovation activity, vacancy.

JEL Classification: J20, M5, L74, N60, E20, F65

\section{Introduction}

All designers, both in the field of capital engineering, as well as in the sphere of construction are related with a single regulatory base (standards, norms, instructions, etc.) with some specialization and direction. With no exception, all the designers are the creative workers of the various professions. Depending on the type and purpose of objects design engineers are divided into architects, engineers, technologists, constructors and artistic constructors or designers. Creativity, which determines the creative nature of the work, is an integral part of their professional thinking. The ability to invent, i.e. to accept new, unconventional and original design decisions, is defined by the ability to work creatively. The level of creativity includes in its orbit all the spiritual and mental powers of the master and is the highest level of the development of the mindset. All of that has to be paid well and bring satisfaction from the done work. The article aims to demonstrate the assessment of the financial stand of the design engineer of the design enterprise in the period of the economic crisis in Ukraine and in a number of the foreign countries. Expansion of the research provides the idea of the dynamics of vacancies and salaries for engineers of design enterprises in a specific economic context.

\section{Influence of crisis on the profession "Design engineer"}

2020 is not just the year of the COVID-19 pandemic, but also a crisis with all the consequences. Coronavirus has sent tremors through the labour market among the design engineers - in Ukraine for one vacancy there are already 11 unemployed candidates. According to recent data, there are three times more people looking for work only in Kyiv, than in 2020. Certain design enterprises are on the verge of survival. Investors that are always expecting a possible market collapse have not been ready for such a course of the events, but they even managed to take advantage of that. The COVID-19 pandemic has affected the sphere of investment from the point of view of the fall of assessments on the quality projects. The quarantine has transformed the engineering labour market. The speed of making decisions and innovation implementation in the conditions of quarantine has grown steadily. Design enterprises have been forced to develop new procedures and launch new solutions in a short term. The leading tendency of the current engineering labour market can be multiplied by the growth of the newest options of remote work. A lot of design engineers have good performance even while working at home. The main quality of a modern design engineer is a sense of responsibility.

\section{Review of salary statistics of the profession "Design engineer" in Ukraine}

Today, the average salary of a design engineer per month in Ukraine is 12,663 UAH. As of February 18, 2021, 84 positions for design engineers have been opened in Ukraine. For $32.1 \%$ of open positions, employers have indicated a salary of $13,100+\mathrm{UAH}$, $16.7 \%$ positions with a salary of $7,100+\mathrm{UAH}, 14.3 \%$ positions with a salary of 9,100+ UAH. The number of positions in the profession "Design Engineer" by salary ranges in Ukraine is as follows: salary/number of vacancies: $1,100 \mathrm{UAH}+/ 2 ; 3,100+\mathrm{UAH} / 1$; $5,100+\mathrm{UAH} / 5 ; 7.100+\mathrm{UAH} / 14 ; 9,100+\mathrm{UAH} /$ $12 ; 11,100+\mathrm{UAH} / 6 ; 13,100+\mathrm{UAH} / 27 ; 15,1+$ $\mathrm{UAH} / 5 ; 17,100+\mathrm{UAH} / 3 ; 19,000+\mathrm{UAH} / 9$. Over the last 12 months in Ukraine the level of the average salary of the Design Engineer has been: February 2020 11,039 UAH; March 2020 - 13,534 UAH; April 2020 - 
13,840 UAH; May 2020 - 13,872 UAH; June 2020 13,106 UAH; July 2020 - 11,516 UAH; August 2020 11,623 UAH; September 2020 - 13,508 UAH; October 2020 - 15,970 UAH; November 2020 11,381 UAH; December 2020 - 10,800 UAH; January 2021 - 11,772 UAH. As of February, 18, 2021, the largest number of positions for design engineers has been opened in Kyiv oblast. In the second place there is Zaporizhzhia oblast, and Ternopil oblast is the third. Positions "Design Engineer" in the regions of Ukraine are distributed as follows: Kyiv oblast - 123 positions $6 \%$, Zaporizhzhia oblast - 98 positions - 4.8\%, Ternopil oblast -98 positions $-4.8 \%$. Accordingly, the following indicators are obtained: Ivano-Frankivsk oblast, Kirovohrad oblast, Khmelnytskyi oblast, Crimea, Luhansk oblast, Vinnytsia oblast, Lviv oblast, Chernihiv oblast, Volyn oblast, Mykolaiv oblast, Chernivtsi oblast, Odesa oblast, Poltava oblast, Zhytomyr oblast, Rivne oblast, Zakarpattia oblast, Sumy oblast - 98 positions $-4.8 \%$, Kharkiv oblast 32 positions - 1.6\%, Dnipropetrovsk oblast - 14 positions $-0.7 \%$, Donetsk oblast -14 positions $-0.2 \%$, Kherson and Cherkasy oblasts -3 positions $-0.1 \%$. Designers in any field must work with well-equipped information technology, computer systems, and intelligent software. This is a union of designers, both from design bureaus and working in the field of capital construction. Recently, the design process is increasingly focused on the changes that must undergo production and society as a whole and less focused on the developed object. The designer must be able to predict some new state on the basis of modern data, which will occur only if predictions are correct. This is the main difficulty in the work of a designer. The final result of the design has to be assumed even before all the means to obtain them are studied from the consequences to the causes, from the expected impact of this development on the world to the beginning of the chain of events, as a result of which this impact will occur. The designer is forced to follow the events in reverse order. During such follow-up, it often happens that unforeseen difficulties arise at one of the intermediate stages or new, more favourable opportunities open up. The nature of the initial problem may completely change, and the design engineer with his or her directions will be rejected to the starting position. It takes a lot of time and money. According to statistics for February 18, 2021, the profession of Design Engineer is the highest paid in the Kyiv oblast: the average salary is $15,196 \mathrm{UAH}$. Odesa and Dnipropetrovsk oblasts follow it. Rating of regions in Ukraine by the level of average salary for the profession "Design Engineer" as of February 18, 2021 distributs as follows: Kyiv oblast - 15,196 UAH, Odesa oblast - 13,961 UAH, Dnipropetrovsk oblast 12,928 UAH, Kharkiv oblast - 12,146 UAH, Lviv oblast - 11,833 UAH, Donetsk oblast - 10,500 UAH,
Volyn oblast - 9892 UAH, Vinnytsia oblast 9,717 UAH, Kherson oblast - 9,500 UAH, IvanoFrankivsk oblast - 9,275 UAH. For the current period, private enterprises have appeared in Ukraine, which are engaged in the design of individual specialized technical objects. Through engineering work carried out by foreign firms, manufacturing plants and other organizations, there are various trends in design. This is due to market relations and business. Large-scale work must be carried out using design support systems, also with the adoption of scientifically based decisions and taking into account the use of new technologies. The profession of Design Engineer is the highest paid in Kyiv. The salary level is 14,471 UAH. Among similar professions in Ukraine, the most highly paid is the electrical design engineer. The average salary is $20,245 \mathrm{UAH}$. In second place is an HV design engineer with a salary of $19,000 \mathrm{UAH}$. In the third place there is a fire alarm security system design engineer with a salary of 16,407 UAH. Next come: HVAC design engineer - 16,142 $\mathrm{UAH}$, fire protecting design engineer - 15,050 UAH, EC\&I design engineer $15,050 \mathrm{UAH}$, highway design engineer - 14,860 UAH, leading design engineer - 13,664 UAH, gas distribution design engineer - 12,025 UAH, industrial/civil construction design engineer - 9,013 UAH. A number of inherent difficulties have arisen in the domestic design market today. They are associated with both the economic situation and the quality of the services provided. Firstly, competition among design engineers has increased. Competition is a healthy market process. During a pandemic, it is due to a decrease in demand for design services. Secondly, there is the pricing dumping in the construction industry. This state of affairs does not contribute to the growth of professionalism and quality. Thirdly, the trend of consolidation of design enterprises, which has been growing in recent years, speaks of the problems in the design market. Legislative requirements for design and survey activities are being tightened, which leads to the liquidation or merger of small survey and design enterprises and clears the way for large enterprises with state participation. The average monthly salary for the profession "Industrial/civil construction design engineer" is 16,562 UAH. As of February 19, 2021, there are 3 positions open for the industrial/civil construction design engineer in Ukraine. For $66.7 \%$ of open positions, employers have indicated a salary of 7,400+ UAH - 2 positions, $33.3 \%$ positions with a salary of 5,600+ UAH - 1 position, $0 \%$ with a salary of $3,800+\mathrm{UAH}-0$ positions. The following change in the level of the average salary for the industrial/civil construction design engineer for the last 12 months is observed in Ukraine: July 2020 - 23,955 UAH, September 2020 - 10,000 UAH, October 2020 30,830 UAH, November 2020 - 10,025 UAH, December 2020 - 18,000 UAH, January 2021 - 
$8,000 \mathrm{UAH}$. The largest number of positions for the profession of the industrial/civil construction design engineer by regions as of February 19, 2021 is opened in Kherson oblast. The second place is taken by Kirovohrad oblast, and the third is Khmelnytskyi oblast. Industrial/civil construction design engineer, the dynamics of the number of positions in Ukraine for the last 12 months: December $2020-1$ position, January $2021-1$ position. In any country, including Ukraine, there is specialization in design. For example, the design of objects of the urban civil sphere, metallurgical and machine-building plants etc. The design engineer is a professional craftsman who is guided in the formation of accurate diagrams and plans for various structures. In Ukraine, you can successfully find a job in large companies. To do this, you must have experience in design, be familiarized with using special software and applications. High-level specialists are in demand in the country. The remuneration of a design engineer correlates with his or her professional qualities. The key responsibilities of an expert are: formation of projects and accompanying documentation; preparation of data and contracts for work; drawing up detailed plans and schedules; setting clear assignments for contractors; control over the implementation of projects. The devaluation of the hryvnia and the subsequent inflation that occurred during 2014-2015 had a negative impact on the number of orders and the cost of proposals in the construction sector, including design.

\section{Financing of an engineer in foreign countries}

In Belarus, you must have a wealth of practical experience for successful employment. A skilful design engineer gets good money. Professionals earn in various design companies: in Minsk - from 1,000 BYN per month; in Gomel private design organization - up to $1,500 \mathrm{BYN} / 750 \mathrm{USD}$, in Vitebsk - salary in the range from 1,000 to $2,500 \mathrm{BYN} / 500-1,250$ USD. The organization implements orders from private entrepreneurs.

In Poland, the average salary of a design engineer in 2019 was 8,539 PLN per month. The salary of engineers in Poland ranges from 4,430 PLN (1,135.88 USD) per month (minimum wage) to 10,634 PLN (2,726.63 USD) per month (maximum salary). Salaries vary between different engineering jobs. Average salary of a design engineer in Poland in recent years: Average salary in $2016-7,248$ PLN. Average salaries of engineers in Poland $2017+4 \%-7,516$ PLN. Average salary in 2018 $+3 \%-7,772$ PLN. Average salary $2019+3 \%-8,013$ PLN. The salary of engineers in Poland is growing in 2019 based on submitted salaries and reports. Salary in 2019 is 3\% higher than in 2018. This trend is indicative of slow but steady growth in wages in 2020 and beyond. The average hourly wage in Poland for design engineers is 46 PLN (11.79 USD). This means that the average person in Poland earns approximately 46 PLN per hour worked. Hourly Wage $=$ Annual Wage $\div(52 \times 5 \times 8)$. Hourly wages are wages paid for one working hour. Typically, jobs fall into two categories: paid and hourly jobs. For hired work, a fixed amount is paid regardless of the hours worked. Hourly wages per hour of work: the above formula is used to convert wages to hourly wages (assuming 5 working days a week and 8 working hours a day, which is the standard for most jobs). The calculation of hourly wages may vary slightly depending on weekly working hours and annual vacation allowance. The numbers above are a good approximation and are considered standard. In Poland, engineering salaries are $11 \%$ lower than all other workers. For the period of 2019 , the average salary of a design engineer in the cities of Poland is as follows: Gdansk - 7,300 PLN; Katowice - 6,657 PLN; Krakow - 8,783 PLN; Lublin - 6,875 PLN; Poznan - 7,515 PLN; Szczecin - 7,084 PLN; Warsaw - 9,021 PLN; Wroclaw - 8,545 PLN. In the face of tough restrictive measures related to the coronavirus epidemic, the Polish government is trying to save the country's economy, in particular in design enterprises. The country's Council of Ministers has prepared the so-called "Anti-Crisis Shield", i.e. a programme of economic support in the country in the amount of 212 billion PLN (approximately 45 billion EUR).

In Italy as of February 24, 2017 the following data id observed. Engineering graduates continued to be among the categories most likely to find a job after graduation, with a high level of employment and an average salary of 1,400 EUR. They are among the most demanded in the work. Research conducted by the National Council of Examiners for Engineering and Surveying (NCEES), on the inclusion of employing graduates with engineering skills. Analysis of post-graduation employment data for one and five years shows an extremely positive picture for graduating engineering classes: one year after graduation, about two-thirds are employed, compared with $55 \%$ of all graduates. After a few years, the situation has been improved; the employment rate is exceeded by $88 \%$. The unemployment rate remains one of the lowest among graduates with engineering skills: one year after graduation, it is actually $10.5 \%$ (lower than in 2013) versus $20.6 \%$ registered among all graduates. Unemployment drops to $3.8 \%$. This indicates a situation of full employment and unemployment. Average net monthly earnings increased slightly again after a period of gradual decline. Engineering graduates in 2010, five years after graduation, earn more than $1,700 \mathrm{EUR}$, which is 300 EUR more than the average for all graduates. The average salary of engineering graduates is the highest among all graduates a year after graduation, almost 1,400 EUR. After graduation, this leadership remains even after five years, when it reaches more than 1,700 EUR. The salary level varies depending on the manufacturing sector in which graduates with 
engineering skills do their jobs: in fact, they range from 1,542 EUR for those in professional research to almost 1,850 EUR for people in the energy sector.

In the first quarter of 2019, Germany needed 86,300 engineering professionals. The number of open positions has grown by $7-8 \%$ annually since 2011 . This is a countrywide disaster. The German labour market offers 34,000 job positions in construction for engineers. At the same time, 22 thousand engineers in Germany are officially unemployed. The age of workers active in the labour market incentifies the problem. There is no such number of working engineers over the age of 55 in any other country in the Eurozone. On average in Europe, 15\% of workers are people of older age. The situation with young people is even worse. In European countries, about $35 \%$ of engineers are under 35 years old, in Germany there are only $18 \%$. The German government is taking action. A lot of efforts have been made to replenish the engineering ranks. In 2016, 127,000 new engineers were trained in German universities - three times more than in 2005. But the upward trend in the number of people who are trained in engineering does not cover the ever-growing demand. The German economy is very engineering intensive. In Germany, the salary of an engineer in the construction industry is 42,000 EUR. An engineer with ten years of experience earns 70,000-80,000 EUR per year in Germany. Design engineers in Germany (IngenieurKonstruktion) receive a salary of 3,099-4,743 EUR. Their main task is to develop and test concepts for new technologies and production processes.

In Finland, the average salary for design engineers in 2016-2020 has been changed as follows: $2020-$ monthly - gross 4,270 EUR, monthly - net 3,085 EUR, the gap with the previous year is $+1.5 \%$; 2019 monthly - gross 4.207 EUR, monthly - net 3,051 EUR, the gap with the previous year is $+3 \%$; 2018 - monthly gross 4,068 EUR, monthly - net 2,976 EUR, the gap with the previous year is $+2 \% ; 2017$ - monthly - gross 3,980 EUR, monthly - net 2,928 EUR, the gap with the previous year is $+4 \%$; 2016 - monthly - gross 3,838 EUR, monthly - net 2,848 EUR. Sources of salaries for engineers of different levels and fields of activity in Finland are the Finnish job portals, as well as the resource kt.fi with statistics from municipal employers. Salaries earned by employees in Finland usually consist of a base amount determined according to their level in the salary scale and allowances from overtime and other bonuses received on the basis of work performed. Below are the earnings of Finnish engineers by workplace and specialization, taking into account the proportion of female staff and the final average monthly wage earned net after paying standard taxes. Today, in Finland, design engineers receive: monthly - gross - 4,483 EUR, monthly - net - 3,200 EUR.

In Canada, engineers are one of the most soughtafter professions. The average salary for engineers can be higher than in other industries. For 2020, according to the official Canadian portal JobBank, the average salary for an engineer was about $\$ 80,000$ per year $(\$ 6,667$ per month), design engineer - $\$ 79,357$ per year (\$ 6,613 per month), project engineer $-\$ 82,737$ per year, ( $\$ 6,895$ per month).

In the United States, one of the most sought-after professions that provide a good income is an engineer. Skilled workers are valuable, so the wages of engineers in the field of engineering are significantly higher than the average wage in the country. Engineering professionals in the United States earn \$ 48 an hour, nearly 7 times the minimum and 2 times the average wage for a skilled worker. However, the salaries of engineers in the United States can fluctuate significantly. The level of remuneration depends on many factors, including education - the difference in income between a bachelor's degree and an employee with an academic degree can be quite noticeable. Average salary of engineering graduates: Bachelor's graduate - 86, 000 USD; Master's degree graduate - 96,000 USD; Doctoral graduate - 115,000 USD. The salary is influenced by the experience, the level of professional training of the specialist and the region of employment. For example, Californian engineers can expect higher salaries than their Oklahoma or Tennessee counterparts. However, the cost of living in these states will be substantially lower than in California. Specialization is important, as the average salary for a design engineer in the United States is highly dependent on the industry. Average salary by specialization: production engineer 80,000 USD; mechanical engineer - 85,000 USD; electrical engineer - 90,000 USD. In the United States, gender pay gap still persists. This is evidenced by the numbers that show how much an engineer earns in the United States. On average, men earn 20-25\% more than women working in similar positions. However, this difference is narrowing every year. Over the past years, the need for engineers in American companies has steadily increased. The number of vacancies increased by $10 \%$. Representatives of engineering specialties are in demand in all production areas, including construction. Given the ever-increasing demand, the salary of an engineer in the United States will constantly rise.

\section{Conclusions}

According to the survey conducted during the coronavirus crisis in May 2020, about half of the surveyed Ukrainian design companies cut their salaries by $20-30 \%$, and $35 \%$ of employers planned to further reduce salaries. Approximately $65 \%$ of the respondents have planned to adhere to the current wage level. Despite the severe dip in wages and employment, the labour market is recovering rather quickly. The coronavirus crisis was not originally economic. The engineering labour market in Ukraine is beginning to recover from 
the crisis. The demand for design engineers is gradually recovering. According to statistics from the four largest recruiting companies, the number of new vacancies has ceased to decline. This positive trend is confirmed by the data of the State Statistics Service. There was no revolution in the engineering labour market due to the COVID-19 pandemic. The data used were: job search site Work.ua, personnel portals rabota.ua, HR provider Smart Solutions, HeadHunter, EY consulting company in Ukraine, international freelance exchange Proffstore.com. Currently, the Ukrainian engineering labour market can be considered an "employer market". Over the past decade, freelance work on individual projects has grown from the lot of creative people into an industry with a multi-billion dollar turnover. Freelancing can already be considered as a full-fledged and rather significant part of the Ukrainian engineering labour market. Remote work is the future. The world is changing. It is difficult to realize how fast the speed of change is. The rate of change increases, the complexity of professional tasks increases. Humanity has never rushed so fast before. Hundreds of new professions are being created by storms of innovation. They send specialities that seemed to guarantee a comfortable existence ten years ago to the dustbin of history. The knowledge acquired by students becomes obsolete even before they are awarded a diploma. Today, the establishment of permanent cooperation with Ukrainian design enterprises that already have their offices abroad, as well as with existing foreign design/construction companies is effective. The future of design can only be predicted in the short term. It consists of digital information models, advanced outsourcing and augmented reality technologies. Global harmonization of norms and standards is inevitable. Specialization of design engineers will gradually lead to the emergence of new directions and to the consolidation of the market in relation to the cost and integration of design technologies. Design enterprises are the first to feel changes in the economy. This is due to the fact that the development of demand for design services is largely due to the state and trends of the construction market. Ukraine has every chance to occupy key positions in the world market of design services in construction. This article is intended to assess the financial situation of design engineers of design enterprises in construction in Ukraine. Today Winston Churchill's expression "To improve is to change. To be perfect is to change often" is more relevant than ever.

\section{References:}

Egorshin, A. P. (2015). Motivation and stimulation of labour activity [Text]. Moscow: INFRA.

Lityagin, A. A. (2002, February). Optimization of staff pay. Tips for top managers [Text]. Business without problems - Staff.

Greshchak, M. H., Grebeshkova, O. M., \& Kotsyuba, O. S. (2001). Internal economic mechanism of the enterprise. Kyiv: KNEU.

Kuzntsova, M. S. (2020). State Statistics Service of Ukraine Statistical Book "Science and Innovation Activity of Ukraine for 2019 Rik". Kyiv.

Shmig, G. A. (Ed.), Boyarchuk, V. M., Dobriansky, I. M., \& Barabash, V. M. (2010). Designing Terminological dictionary-reference book on construction and architecture. Lviv.

Borisenko, B. M., \& Ryabenko, L. I. (2005). Currency and financial mechanism of economic activity of Ukrainian enterprises. Ekonomika Management Pidpryiemnstvo, vol. 13, pp. 100-105.

Vetluzhskikh, E. N. (2013). Motivation and remuneration. Tools. Techniques. Practice. Alpina Publisher. 5th ed. Moscow.

Velichko, E. A., \& Davydovsky, F. N. (2016). Methodological foundations of bonuses for engineers of the design bureau based on the results of the assessment of labour contribution. International Journal of Applied and Basic Research, vol. 11-1, pp. 109-112. Available at: http://elibrary.ru/download/98192422.pdf

Jones, J. K. (1986). Design Methods [Text]: per. from English. 2nd ed., Add. Moscow: World.

Davydovsky, F. N. (2014). The system of remuneration and the problem of material remuneration of engineering and technical workers involved in the implementation of innovative projects. Issues of innovation economy. Creative economy, vol. 2(16), pp. 13-21. Available at: http://bgscience.ru/lib/10067/

Likhanova, M. S., \& Bondarenko, O. V. (2014). Problems in the field of wages as a factor of destabilization in the labour market for engineering personnel. Modern high technologies, vol. 7-3, pp. 59-60. Available at: http://www.top-technologies.ru/ru/article/view?id=34515

Morgachov, I. B. (2006). Organizational and economic mechanism for managing the effective performance of design organizations. Schedule, vol. 5(77), pp. 88-92.

Pryazhnikov, N. S., Vasyakin, B. S., \& Deberdeeva, N. A. (2016). Promising approaches to solving the problem of accounting for the individual contribution of an employee. Rationing and wages in industry, vol. 10, pp. 18-25.

Posokhova, S. V., \& Eskov, O. L. (2002). Organizational-economical principle of formulating the mechanism of payment for work. Ekonomika Management Pidpryumnstvo, vol. 9 (II), pp. 175-179.

Babkin, S. (2019, 19.07). The profession of an engineer in Germany. Available at: https://www.tupa-germania.ru/ rabota/trebuemye-professii-inzhener.html 
Gurieva, M. Salary of Engineers in the USA - Study America. How much do engineers earn in dollars. Available at: https://study-america.org/bazaznaniy/zarplata-inzhenera-v-ssha

Kuznetsova, N. (2020). Average and Minimum Salaries in Canada 2020: A Complete Review. Available at: https://vancouverok.com/zarplati-v-kanade

Engineering average salaries in Finland Updated (2020,18.12). Available at: https://zarplata-es.com/inzhenernyesrednie-zarplaty-v-finljandii/

Bulinkova, O. Yu. (2010). Dynamics of the capital of the enterprises of the weekday halls in 2005-2010 rock. Scientific-practical conference of young scholars, postgraduates and students of KNUBA: theses of additional topics. Kyiv.

Vakhovich, I. V., Yachmenova, Yu. V., Tereshchenko, L. V., \& Bulinkova, O. Yu. (2018, May 23-24). Actual directions of improving the pricing system in the construction of Ukraine. Materials of the $\mathrm{V}$ international scientific and practical conference BIM-technologies, Methodology and principles of pricing in construction. Innovative technologies in the construction industry and their implementation. Minsk: Belarus. 